水一メタノール溶媒中に於ける溶解度に就て各種のデ 一タ及び 4 成分系，3成分系の相図を提出している。 この5ち次の 4 成分系につき特に詳細な研究が行わ れた。郎ち,

メタノールー水一パラクレゾールーメチルナフタリン メタノール一水一フェノールーメチルナフタリン

てれらの図表及びデータから考察し, 次の結論が得 られた。

1. $\times$ タノール $70 \%(\mathrm{wt})$ 一水 $30 \%(\mathrm{wt})$ 程度の 場合に溶解能及び撰択性の関係が最も良好である。

2. 然し，水一メタノール系溶媒のみではタール酸 フリー炭化水素の分蕹に有勃でなく，次にパラフィン 系炭化水素溶媒老用い，再抽出を行与必姴があり，乙 の溶媒は蒸溜により分離出來るよらに溶質炭化水素を 相当沸点の異つた物質を撰ぶべきである。

3. 予期された事であるが芳香炭族化水素中ではフ エノール類は相当の溶解度を示すが，パラフイン系炭 化水素ではそら溶解性を有しない。

4. すざての采に見られるが水一メタノール溶媒中 のメタノール泣炭化水素層に幾分溶解し, 溶媒層の溶 媒組成は水の含有量を增大する。併しての変化は僅か で，結局ター几酸の分離する傾问を增大する。（常富）

\section{タール, ピツチの熱容量と熱含量}

(D. Hyman \& W. B. Kay, Ind. \& Eng. Chem., 41, 1949, 1764)

巡回空武浴中の眞空フラスコよりなるカロリメータ 一（裝置及び操作の詳細が記述されている）により水 成ガスタール，コークス炬タール及び夫々より得られ たビッチの熱容量が $100 \sim 600^{\circ} \mathrm{F}$ の盜度範团に於て測 定された。熱容量な溫度と直線的な関係にある。加熱 ピッチを放冷せる場合なだらかな溫度降下を示し特定 の熔融熱の放出は見られない。比重及びベンゼン可溶 分をパラメーターとし熱容量の溫度に対する関係式が 得られた。

$$
\begin{aligned}
& C=1 / D(0.302+0.000656 t) \\
& C=S(0.321+0.000694 t) \cdots
\end{aligned}
$$

$\mathrm{D}$ : 比重 $60 / 60^{\circ} \mathrm{F}, \mathrm{S}:$ ベンゼン可溶分,

$\mathrm{C}: \mathrm{Btu} /{ }^{\circ} \mathrm{F} / \mathrm{lb}$.

実測値の実驗式よりの本均偏差は (1) 式で $3.2 \%$, (2) 式で $4.2 \%$ でありょく一致している。

熱含量は前式を積分して次の如く表わされる。

$$
\begin{aligned}
& \mathrm{H}=1 / \mathrm{D}\left(0.302 \mathrm{t}+0.000328 \mathrm{t}^{2}-19.3\right) \\
& \mathrm{H}=\mathrm{S}\left(0.321 \mathrm{t}+0.000347 \mathrm{t}^{2}-20.5\right)
\end{aligned}
$$

$\mathrm{H}: 60^{\circ} \mathrm{F}$ 以上K於て $\mathrm{Btu} / \mathrm{lb}$.

\section{ガ ス 体 燃料}

\section{Hypersorption 法に依るエチレンの回收}

(H. Kehde, R. G. Fairfield, J. E. Frank \& L. W. Zahnstecher, Chem. Eng. Progress, 44, 1948, 575)

Hypersorption 法は流動層を用いて活性炭に依り， ガスを連続分離するものである。

現在は主にエチレンの回收に用いられているが，著 “者等は本報告に於て, ミシガン州ミッドランドの Dow Chem. Co.のプラントに就てその裝置，操作を述心 ている。このプラントは $75 \mathrm{lb} / \mathrm{in}^{2}$ (ゲーヂ压) Кて原 料ガス $1,800,000 \mathrm{ft}^{3} /$ 日の処理能を有するもので, 活 性炭の最高偱環量は $32,000 \mathrm{lb} / \mathrm{hr}$ ，そのエチレン放散 溫度は $500^{\circ} \mathrm{F}$ である。

分離塔は直徑 $4.5 \mathrm{ft}$ 高さ $85 \mathrm{ft}$ のものである。原料 ガスを分離塔の略々中央のトレイより挿入すると，そ の重質成分を吸着した活性炭々次第に下降してトレイ の下部に在る精溜部に於て重質ガスの逆流と接触し吸 着した軽，中質ガスを分離し，軽質ガスは最初より吸 着されないガスと共に塔の上部より分離され，中質が スは挿入トレイとその上部に在る冷却器との中間より 分離される。重質ガスで飽和された活性炭は更に下降 し Dow therm 加悠パイプを涌る時，下より來る水蒸 気に依つて重質成分を放散し，乙れは精溜部と放散部 の中間のトレイに依り流動層々分離される。活性炭ね 上部の軽質ガスの一部に依り再循環且つ整粒される。

てのエチンン回收は，例えば水素 $39.8 \%$ ，メタン $51.3 \%$ ，エチレン $5.8 \%$ のガスに対し分離結果は，軽 質がス (33.2\%) に水素 $61.8 \%$ ，タン $33.7 \%$ ，未分 離エチレン $0.4 \%$ ，中質ガス $(60.6 \%)$ に水素 $31.6 \%$ メタン $66.1 \%$ ，重質がス (6.5\%) Kエチレン $92.7 \%$ の如くに行わ挑，との收量，純度は原料がスに予定含 量の $400 \%$ のエチレンを含む場合も，数時間に亘りエ チレンを吸着分離したと云われる。原料ガスとして， 熱分解及び接触分解ガスの水素より $\mathrm{C}_{4}$ 炭化水素位の 混合ガス壳，水素一メタン， $\mathrm{C}_{2}$ 炭化水素， $\mathrm{C}_{3}$ 以上の 如くに分離し，プロパン分解プラントと組合せて $\mathrm{C}_{2}$ 炭化水素を分離し，未分解プロパンを再偱環させる。

Hypersorption 法はェチレン回收のみでなく，その 施設費, 操業費の低廉な事, 製品ガスの收量, 純度の優 れている事より基本的な気相分離法となり得るすので， 部分酸化法或は電弧法に依るアセチレンに対する精製， 天然ガスよりメタン，エタン，プロパン，ブタンの分 離，水素の精製等にも使用し得るるのである。（保正） 